\title{
BMJ Global Health Reduction of secondary transmission of SARS-CoV-2 in households by face mask use, disinfection and social distancing: a cohort study in Beijing, China
}

Yu Wang, ${ }^{1}$ Huaiyu Tian, ${ }^{2}$ Li Zhang, ${ }^{1}$ Man Zhang, ${ }^{3}$ Dandan Guo, ${ }^{4}$ Wenting Wu, ${ }^{1}$ Xingxing Zhang, ${ }^{3}$ Ge Lin Kan, ${ }^{5}$ Lei Jia, ${ }^{1}$ Da Huo, ${ }^{1}$ Baiwei Liu, ${ }^{1}$ Xiaoli Wang, ${ }^{1}$ Ying Sun, ${ }^{1}$ Quanyi Wang, ${ }^{1}$ Peng Yang, ${ }^{3}$ C. Raina Maclntyre ${ }^{6,7}$

To cite: Wang $\mathrm{Y}$, Tian $\mathrm{H}$, Zhang $L$, et al. Reduction of secondary transmission of SARS-CoV-2 in households by face mask use, disinfection and social distancing: a cohort study in Beijing, China. BMJ Global Health 2020;5:e002794. doi:10.1136/ bmjgh-2020-002794

Handling editor Seye Abimbola

Received 1 May 2020

Revised 9 May 2020

Accepted 11 May 2020
Check for updates

(c) Author(s) (or their employer(s)) 2020. Re-use permitted under CC BY-NC. No commercial re-use. See rights and permissions. Published by BMJ

For numbered affiliations see end of article.

\section{Correspondence to} Dr Quanyi Wang; wangquanyi@protonmail.com and

Dr Peng Yang;

yangpengcdc@163.com

\begin{abstract}
Introduction Transmission of COVID-19 within families and close contacts accounts for the majority of epidemic growth. Community mask wearing, hand washing and social distancing are thought to be effective but there is little evidence to inform or support community members on COVID-19 risk reduction within families.

Methods A retrospective cohort study of 335 people in 124 families and with at least one laboratory confirmed COVID-19 case was conducted from 28 February to 27 March 2020, in Beijing, China. The outcome of interest was secondary transmission of severe acute respiratory syndrome coronavirus 2 (SARS-CoV-2) within the family. Characteristics and practices of primary cases, of well family contacts and household hygiene practices were analysed as predictors of secondary transmission.
\end{abstract}

Results The secondary attack rate in families was $23.0 \%$ (77/335). Face mask use by the primary case and family contacts before the primary case developed symptoms was $79 \%$ effective in reducing transmission $(\mathrm{OR}=0.21$, $95 \% \mathrm{Cl} 0.06$ to 0.79 ). Daily use of chlorine or ethanol based disinfectant in households was $77 \%$ effective ( $0 \mathrm{R}=0.23,95 \% \mathrm{Cl} 0.07$ to 0.84 ). Wearing a mask after illness onset of the primary case was not significantly protective. The risk of household transmission was 18 times higher with frequent daily close contact with the primary case $(\mathrm{OR}=18.26,95 \% \mathrm{Cl} 3.93$ to 84.79$)$, and four times higher if the primary case had diarrhoea $(0 \mathrm{R}=4.10$, $95 \% \mathrm{Cl} 1.08$ to 15.60). Household crowding was not significant.

Conclusion The study confirms the highest risk of transmission prior to symptom onset, and provides the first evidence of the effectiveness of mask use, disinfection and social distancing in preventing COVID-19. We also found evidence of faecal transmission. This can inform guidelines for community prevention in settings of intense COVID-19 epidemics.

\section{Summary box}

What is already known?

- Mitigation of the COVID-19 pandemic depends solely on non-pharmaceutical interventions until drugs or vaccines are available. Transmission of COVID-19 within families and close contacts accounts for the majority of epidemic growth. Community mask wearing, hand washing and social distancing are thought to be effective but the evidence is not clear.

What are the new findings?

- The overall secondary attack rate in households was $23.0 \%$. Face masks were $79 \%$ effective and disinfection was $77 \%$ effective in preventing transmission, while close frequent contact in the household increased the risk of transmission 18 times, and diarrhoea in the index patient increased the risk by four times. The results demonstrate the importance of the pre-symptomatic infectiousness of COVID-19 patients and shows that wearing masks after illness onset does not protect.

What do the new findings imply?

- The findings inform universal face mask use and social distancing, not just in public spaces, but inside the household with members at risk of getting infected. This further supports universal face mask use, and also provides guidance on risk reduction for families living with someone in quarantine or isolation, and families of health workers, who may face ongoing risk.

\section{INTRODUCTION}

In the absence of a vaccine for COVID-19, non-pharmaceutical interventions (NPIs) are the only available disease control measures. We have shown that population level NPIs, including travel bans and the national emergency response, were effective in flattening 
the COVID-19 epidemic curve in China. ${ }^{1}$ However, the effect of other NPIs, such as mask use and hygiene practices, have not been well studied in the COVID-19 pandemic.

In the USA, the use of face masks in the community has been recommended. ${ }^{2}$ It is thought that universal face mask use (UFMU) may reduce outward transmission from asymptomatically infected people and protect well people from becoming infected. However, the World Health Organization and Public Health England recommend against UFMU on the grounds that there is little evidence from randomised controlled trials to support this. Some experts suggest that in a pandemic, the precautionary principle should be used and UFMU encouraged as it is unlikely to cause harm and may result in public health gain. ${ }^{34}$ In countries where personal protective equipment is scarce, people are making their own masks.

In China, over $70 \%$ of human-to-human transmission of severe acute respiratory syndrome coronavirus 2 (SARS-CoV-2) occurred in families. ${ }^{5}{ }^{6}$ However, data to inform COVID-19 risk reduction in households are unavailable. Given epidemic growth is dominated by household transmission, ${ }^{56}$ studying the use of NPIs, such as face masks, social distancing and disinfection in the household setting, may inform community epidemic control and prevent transmission of COVID-19 in households.

\section{METHODS \\ Study population and design}

We conducted a retrospective cohort study involving families of laboratory confirmed COVID-19 cases in Beijing, China. We defined family members as those who had lived with primary cases in a house for 4 days before and for more than 24 hours after the primary cases developed illness related to COVID-19. As of 21 February 2020, all laboratory confirmed COVID-19 cases reported in Beijing were enrolled in our study and followed-up. The outcome of interest was secondary transmission in the household. Families with secondary transmission were defined as those where some or all of the family members become infected within one incubation period (2 weeks) of symptom onset of the primary case.

To analyse the predictors of household transmission, we compared families with and without secondary transmission for various measured risk factors, preventive interventions and exposures.

\section{Definition of confirmed case}

According to national prevention and control guideline (fifth edition), ${ }^{7}$ confirmed cases were those who met the clinical, epidemiological and laboratory testing criteria for COVID-19 simultaneously.

1. Clinical criteria included: (a) fever and/or one or more respiratory symptoms; (b) radiological evidence of pneumonia; (c) white blood cell count normal or decreased, and lymphocyte count decreased at the early stage of illness.

2. Epidemiological criteria included: (a) visits to/living in Wuhan or cities around Wuhan or other communities which had already reported COVID-19 cases in the 14 days prior to the onset of symptoms; (b) having contact with a person known to have infection with SARS-CoV-2 in the 14 days prior to onset of symptoms; (c) having contact with a person who had fever or respiratory symptoms and came from Wuhan or adjacent cities or other communities which had already reported COVID-19 cases in the 14 days prior to onset of symptoms; (d) being one of the cluster cases.

Suspected cases met one of the epidemiological criteria and any two of the clinical criteria, or met all of the clinical criteria. Confirmed cases were those suspected cases who met one of the following criteria: (a) respiratory or blood specimen tested positive for SARS-CoV-2 by real time reverse transcriptase-polymerase chain reaction; (b) virus in respiratory or blood specimen was highly homologous with known SARS-CoV-2 through gene sequencing.

\section{Data collection}

A three part structured questionnaire was developed. The first part included demographic and clinical information of the primary case. The second part was mainly focused on the primary case's knowledge about and attitudes toward COVID-19, and their self-reported practices (mask wearing, social distancing, living arrangements) and activities in the home. The third part was about self-reported behaviours of all family members, as well as the family's accommodation and household hygiene practices from 4 days before the illness onset to the day the primary case was isolated, including room ventilation, room cleaning and disinfection. Close contact was defined as being within $1 \mathrm{~m}$ or 3 feet of the primary case, such as eating around a table or sitting together watching TV. The frequency of contact, disinfection and ventilation was measured.

After diagnosis, the primary case was hospitalised as per standard practice in Beijing. Eligible primary cases and their family members were interviewed between 28 February and 8 March. Data on the primary case were extracted from epidemiological investigating reports from Beijing Centre for Disease Prevention and Control and supplemented by interview.

The clinical severity of the COVID-19 case was categorised as mild, severe or critical. Mild disease included nonpneumonia and mild pneumonia cases. Severe disease was characterised by dyspnoea, respiratory frequency $\geq 30 / \mathrm{min}$, blood oxygen saturation $\leq 93 \%, \mathrm{PaO} 2 / \mathrm{FiO} 2$ ratio $<300$ and/or lung infiltrates $>50 \%$ within $24-48$ hours. Critical cases were those who exhibited respiratory failure, septic shock and/or multiple organ dysfunction/ failure. ${ }^{8}$ 


\section{Statistical analysis}

Risk factors for secondary transmission were analysed by characteristics of the primary case, characteristics of well family members and household hygiene practices. Categorical variables are presented as counts and percentages, and continuous variables as medians (IQR). The $\chi^{2}$ test and Fisher exact test were applied to compare difference between groups when necessary. A composite COVID-19 knowledge score and hand hygiene score were created with multiple sub-questions. A multivariable logistic regression model was used to identify risk factors associated with SARS-CoV-2 household transmission. Univariable analysis was first performed with all measures and only those variables significant at $p<0.1$ could be selected in the following multivariable logistic regression analysis. Backward elimination was performed to establish a final model retaining those with $p<0.05$ in the model. Statistical analyses were performed using SAS software (V.9.4).

\section{Ethics statement}

As our study was embedded within the COVID-19 prevention and control practice within public health units, and the telephone interview was a supplementary survey of the epidemiological field investigation, ethics approval was not required. We obtained subjects' verbal informed consent before the start of the interviews.

\section{Patient and public involvement}

No patients or the public were involved in the study design, setting the research questions, interpretation or writing up of results, or reporting of the research.

\section{RESULTS}

As of 21 February 2020, 399 confirmed COVID-19 cases in 181 families were reported in Beijing. Four family clusters were excluded because we were unable to determine whether there was secondary transmission or co-exposure, leaving 177 families. After reviewing information in the epidemiological investigation reports and survey calls, 40 families were excluded as they did not meet the study inclusion criteria. A further 13 families declined to be interviewed and were also excluded, leaving 124 families for study (figure 1).

Over the 2 weeks of follow-up from onset of the primary case, secondary transmission occurred in 41/124 families (77 secondary cases), and 83/124 families had no secondary transmission. The overall secondary attack rate in families was $23.0 \%(77 / 335)$. In the secondary transmission group, 41 primary cases caused 77 secondary cases, with a median secondary case number in families of 2 (IQR 1-2). In the secondary transmission group, the secondary attack rate in children $<18$ years of age was $36.1 \%(13 / 36)$, compared with $69.6 \%$ (64/92) in adults, and the difference between these two age groups was significant $\left(\chi^{2}=12.08, p<0.001\right)$. The median age of the 13 secondary child cases was 3 years (IQR 2-6), 12/13 were

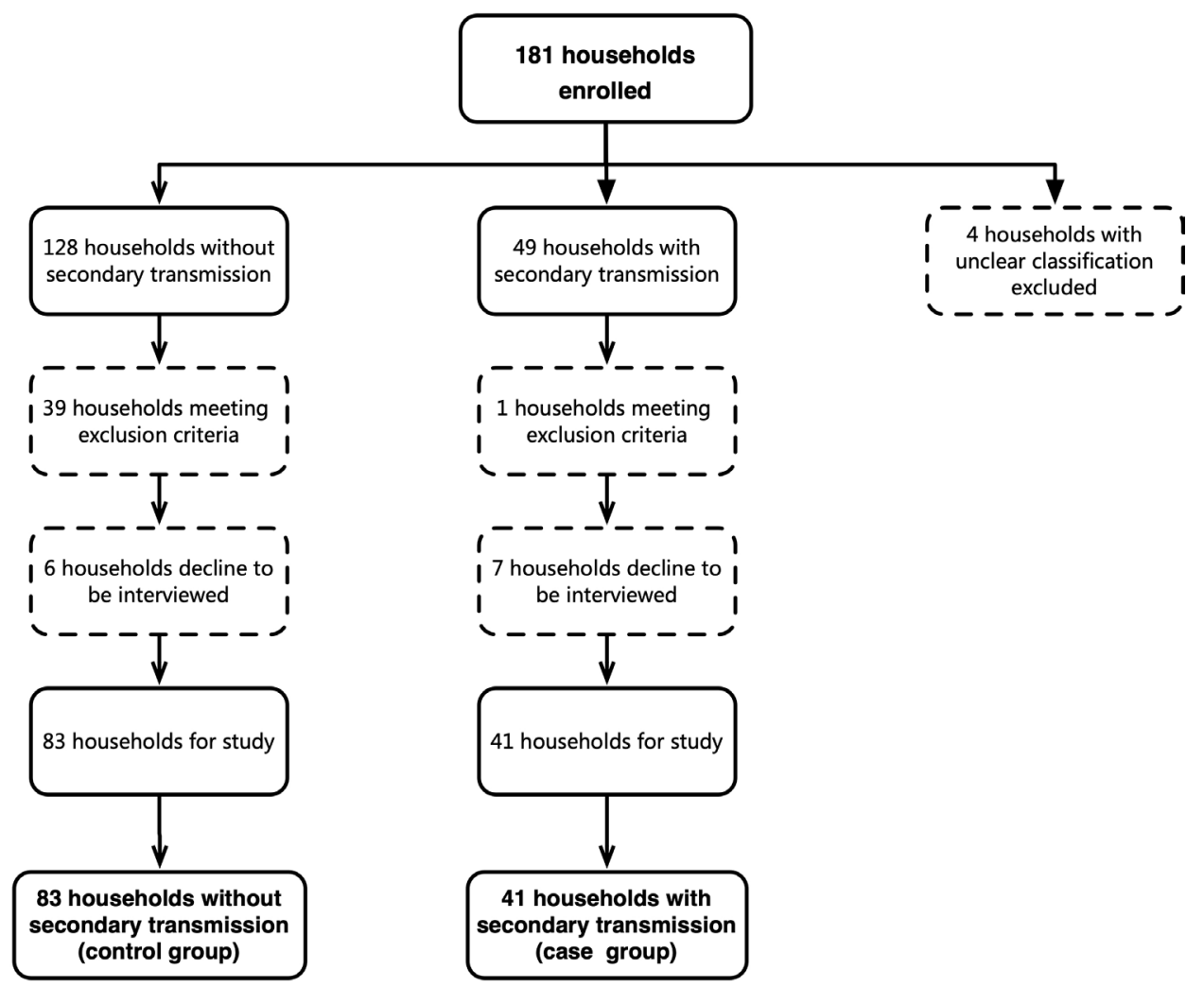

Figure 1 Selection and inclusion of interviewing subjects. Summary of household enrolment, and inclusion and interview response in the analysis of SARS-CoV-2 household transmission in Beijing, China. 
Table 1 Characteristics of primary cases of COVID-19: univariable analysis

\begin{tabular}{|c|c|c|c|c|c|}
\hline Primary cases & $\begin{array}{l}\text { Total }(n(\%)) \\
(n=124)\end{array}$ & $\begin{array}{l}\text { Families without } \\
\text { transmission (n (\%)) } \\
(n=83)\end{array}$ & $\begin{array}{l}\text { Families with } \\
\text { transmission }(n \\
(\%))(n=41)\end{array}$ & $P$ value & $\begin{array}{l}\text { Unadjusted OR } \\
(95 \% \mathrm{Cl})\end{array}$ \\
\hline Age (years) (median (IQR)) & $45.0(35.7-60.0)$ & $42.0(34.0-57.5)$ & $52.0(39.3-61.0)$ & - & - \\
\hline $18-59$ & $92(74.2)$ & $63(75.9)$ & $29(70.7)$ & - & Ref \\
\hline$\geq 60$ & $32(25.8)$ & $20(24.1)$ & $12(29.3)$ & 0.54 & $1.30(0.56$ to 3.02$)$ \\
\hline Men & $61(49.2)$ & $40(48.2)$ & $21(51.2)$ & - & Ref \\
\hline Women & $63(50.8)$ & $43(51.8)$ & $20(48.8)$ & 0.75 & $0.89(0.42$ to 1.87$)$ \\
\hline Education level & - & - & - & - & - \\
\hline High school or lower & $26(21.0)$ & $18(21.7)$ & $8(19.5)$ & - & Ref \\
\hline Bachelor degree & $69(55.6)$ & $47(56.6)$ & $22(53.7)$ & 0.53 & 0.75 (0.30 to 1.86$)$ \\
\hline Severe & $20(16.1)$ & $16(19.3)$ & $4(9.8)$ & 0.22 & $0.48(0.15$ to 1.54$)$ \\
\hline Critical & $8(6.5)$ & $4(4.8)$ & $4(9.8)$ & 0.38 & $1.91(0.45$ to 8.13$)$ \\
\hline Fever $\left(\geq 37.3^{\circ} \mathrm{C}\right)$ & - & - & - & - & - \\
\hline No & $18(14.5)$ & $9(10.8)$ & $9(22.0)$ & - & Ref \\
\hline Yes & $106(85.5)$ & $74(89.2)$ & $32(78.0)$ & 0.11 & $0.43(0.16$ to 1.19$)$ \\
\hline Cough* & - & - & - & - & - \\
\hline No & 66 (53.2) & $45(54.2)$ & $21(51.2)$ & - & Ref \\
\hline Yes & $58(46.8)$ & $38(45.8)$ & $20(48.8)$ & 0.75 & $1.13(0.53$ to 2.39$)$ \\
\hline Diarrhoea† & - & - & - & - & - \\
\hline$\leq 2$ & 47 (37.9) & 35 (42.2) & $12(29.3)$ & - & Ref \\
\hline$>2$ & $77(62.1)$ & $48(57.8)$ & $29(70.7)$ & 0.17 & 1.76 (0.79 to 3.93$)$ \\
\hline $\begin{array}{l}\text { Time interval from illness onset to medical } \\
\text { isolation (days) (median (IQR)) }\end{array}$ & $5.0(2.0-7.0)$ & $5.0(2.0-7.0)$ & $5.0(3.0-9.0)$ & - & - \\
\hline$\leq 2$ & $32(25.8)$ & $26(31.3)$ & $6(14.6)$ & - & Ref \\
\hline$>2$ & $92(74.2)$ & $57(68.7)$ & 35 (85.4) & 0.05 & $2.66(1.00$ to 7.12$)$ \\
\hline $\begin{array}{l}\text { Time interval from illness onset to } \\
\text { laboratory confirmation (days) (median } \\
\text { (IQR)) }\end{array}$ & $7.0(4.7-10.2)$ & $7.0(4.4-9.9)$ & $8.0(5.6-12.9)$ & - & - \\
\hline$\leq 3$ & $16(12.9)$ & $13(15.7)$ & $3(7.3)$ & - & Ref \\
\hline$>3$ & $108(87.1)$ & $70(84.3)$ & $38(92.7)$ & 0.20 & $2.35(0.63$ to 8.77$)$ \\
\hline $\begin{array}{l}\text { Knowledge score on COVID-19 before } \\
\text { illness onset (14 in total) (median (IQR))§ }\end{array}$ & $5(0-9)$ & $5(0-9)$ & $5(0-10)$ & - & - \\
\hline$\geq 10$ & $31(25.0)$ & $18(21.7)$ & $13(31.7)$ & - & Ref \\
\hline $3-9$ & $45(36.3)$ & $32(38.6)$ & $13(31.7)$ & 0.24 & $0.56(0.22$ to 1.47$)$ \\
\hline$\leq 2$ & $48(38.7)$ & $33(39.7)$ & $15(36.6)$ & 0.33 & $0.63(0.25$ to 1.61$)$ \\
\hline $\begin{array}{l}\text { Self-awareness of being infected with } \\
\text { SARS-CoV- } 2 \text { when developed illness }\end{array}$ & - & - & - & - & - \\
\hline Likely & 45 (36.3) & $35(42.2)$ & $10(24.4)$ & - & Ref \\
\hline
\end{tabular}


Table 1 Continued

\begin{tabular}{|c|c|c|c|c|c|}
\hline Primary cases & $\begin{array}{l}\text { Total }(n(\%)) \\
(n=124)\end{array}$ & $\begin{array}{l}\text { Families without } \\
\text { transmission }(\mathrm{n}(\%)) \\
(\mathrm{n}=83)\end{array}$ & $\begin{array}{l}\text { Families with } \\
\text { transmission (n } \\
(\%))(n=41)\end{array}$ & $P$ value & $\begin{array}{l}\text { Unadjusted OR } \\
(95 \% \mathrm{Cl})\end{array}$ \\
\hline Unlikely & $79(63.7)$ & $48(57.8)$ & $31(75.6)$ & 0.06 & 2.26 (0.98 to 5.21$)$ \\
\hline $\begin{array}{l}\text { Knowledge of their own infectiousness } \\
\text { after illness onset }\end{array}$ & - & - & - & - & - \\
\hline Likely & $84(67.7)$ & $62(74.7)$ & $22(53.7)$ & - & Ref \\
\hline Unlikely & $40(32.3)$ & $21(25.3)$ & $19(46.3)$ & 0.02 & 2.55 (1.16 to 5.61$)$ \\
\hline Wear mask at home after illness onset & - & - & - & - & - \\
\hline Never & $41(33.1)$ & $24(28.9)$ & $17(41.5)$ & - & Ref \\
\hline Sometimes & $37(29.8)$ & $21(25.3)$ & $16(39.0)$ & 0.76 & $1.15(0.46$ to 2.87$)$ \\
\hline All the time & $46(37.1)$ & $38(45.8)$ & $8(19.5)$ & 0.02 & $0.30(0.11$ to 0.82$)$ \\
\hline Self-isolated after illness onset & - & - & - & - & - \\
\hline Yes & $79(63.7)$ & $58(69.9)$ & $21(51.2)$ & - & Ref \\
\hline No & $45(36.3)$ & $25(30.1)$ & $20(48.8)$ & 0.05 & $2.17(1.00$ to 4.70$)$ \\
\hline Eat separately at home after illness onset & - & - & - & - & - \\
\hline Yes & $70(56.5)$ & $54(65.1)$ & $16(39.0)$ & - & Ref \\
\hline No & $54(43.5)$ & $29(34.9)$ & $25(61.0)$ & 0.008 & 2.86 (1.32 to 6.19$)$ \\
\hline Eat with separate tableware & - & - & - & - & - \\
\hline Yes & $81(65.3)$ & $58(69.9)$ & $23(56.1)$ & - & Ref \\
\hline No & $43(34.7)$ & $25(30.1)$ & $18(43.9)$ & 0.14 & 1.78 (0.82 to 3.88$)$ \\
\hline $\begin{array}{l}\text { Score on hand hygiene ( } 8 \text { in total) (with } 11 \\
\text { missing values) (median (IQR)) }\end{array}$ & $8(7-8)$ & $8(7-8)$ & $7(6-8)$ & - & - \\
\hline$\geq 6$ & 103 (91.2) & 68 (93.2) & 35 (87.5) & - & Ref \\
\hline $4-5$ & $7(6.2)$ & $4(5.5)$ & $3(7.5)$ & 0.63 & 1.46 (0.31 to 6.88$)$ \\
\hline$\leq 3$ & $3(2.6)$ & $1(1.3)$ & $2(5.0)$ & 0.28 & 3.88 (0.34 to 44.29$)$ \\
\hline
\end{tabular}

*Primary case ever had the symptom of cough when living with others at home.

†Primary case ever had the symptom of diarrhoea (change of character of stool) when living with others at home.

$\ddagger$ Date on which cases self-reported the appearance of either fever $\left(\geq 37.3^{\circ} \mathrm{C}\right)$ or any respiratory symptom during epidemiological investigation. Date of hospital visit was the earliest date that cases sought medical service for COVID-19 related illness.

$\S A$ composite variable involving the primary case's knowledge on the infectivity of SARS-CoV-2, contagious population, transmission route,

susceptible population, incubation period, common symptoms and preventive measures.

१Refers to the primary case or family members wearing a face mask at home, regardless of whether it was a N95 mask, disposable surgical mask or a common mask, including cloth mask. Wearing masks all the time means the primary case wears a mask all the time except when having dinner or sleeping at home.

${ }^{* *} \mathrm{~A}$ composite variable involving the primary case's hand washing practice, including using running water, washing frequency, using sanitiser and under what conditions.

mild and $1 / 13$ was asymptomatic. Of 64 secondary adult cases, $82.8 \%(53 / 64)$ were mild, $10.9 \%(7 / 64)$ were severe, $1.6 \%(1 / 64)$ was critical and $4.7 \%(3 / 64)$ were asymptomatic. No statistically significant difference was observed in clinical severity between 41 index adult cases (table 1) and 64 secondary adult cases for the secondary transmission group $(p=0.18)$.

The univariable analysis for association with secondary transmission of SARS-CoV-2 within families is shown in tables 1-3. Significant associations were:

1. Characteristics, behaviours and knowledge of the primary case: having diarrhoea, interval from illness onset to medical isolation $>2$ days, self-awareness of being infected with SARS-CoV-2 when the primary case developed the illness, lack of knowledge of their own infectiousness, mask wearing in the home after illness onset, failing to self-isolate and not eating separately were associated with transmission (table 1).

2. Behaviours of family members: having daily close contact with the primary case at home, and number of family members wearing a mask in the home before and after the primary case's illness onset date were associated with transmission (table 2).

3. Household practices: frequency of using chlorine or ethanol based disinfectant for household cleaning and household ventilation duration were protective (table 3).

In multivariable logistic regression model, four factors remained significantly associated with secondary transmission. The primary case having diarrhoea in the home and daily close contact with the primary case in the home increased the risk. Transmission was significantly reduced 
Table 2 Characteristics of well family members: univariable analysis

\begin{tabular}{|c|c|c|c|c|c|}
\hline Family members & $\begin{array}{l}\text { Total }(n(\%)) \\
(n=121)\end{array}$ & $\begin{array}{l}\text { Families without } \\
\text { transmission }(\mathrm{n} \\
(\%))(\mathrm{n}=81)\end{array}$ & $\begin{array}{l}\text { Families with } \\
\text { transmission } \\
(\mathrm{n}(\%))(\mathrm{n}=40)\end{array}$ & $P$ value & $\begin{array}{l}\text { Unadjusted OR } \\
(95 \% \mathrm{Cl})\end{array}$ \\
\hline Family size (median (IQR)) & $4(3-5)$ & $3(3-5)$ & $4(3-6)$ & - & - \\
\hline$\leq 3$ & $56(46.3)$ & $41(50.6)$ & $15(37.5)$ & - & Ref \\
\hline$>3$ & $65(53.7)$ & $40(49.4)$ & $25(62.5)$ & 0.18 & $1.71(0.79$ to 3.71$)$ \\
\hline $\begin{array}{l}\text { Close contact with primary cases at home (within } \\
1 \mathrm{~m} \text { or } 3 \text { feet) (No of times) }\end{array}$ & - & - & - & - & - \\
\hline 0 & $41(33.9)$ & $36(44.4)$ & $5(12.5)$ & - & Ref \\
\hline $1-3$ & $61(50.4)$ & $38(46.9)$ & $23(57.5)$ & 0.005 & 4.55 (1.57 to 13.20$)$ \\
\hline$\geq 4$ & $19(15.7)$ & $7(8.7)$ & $12(30.0)$ & $<0.001$ & 12.34 (3.30 to 46.23$)$ \\
\hline $\begin{array}{l}\text { No of family members wearing mask at home } \\
\text { before primary case's illness onset date (median } \\
(\mathrm{IQR}) \dagger\end{array}$ & $0(0-1)$ & $0(0-2)$ & $0(0-0)$ & - & - \\
\hline None & $90(74.4)$ & $54(66.7)$ & $36(90.0)$ & - & Ref \\
\hline One or more & $31(25.6)$ & 27 (33.3) & $4(10.0)$ & 0.009 & 0.22 (0.07 to 0.69$)$ \\
\hline $\begin{array}{l}\text { No of family members wearing mask at home after } \\
\text { primary case's illness onset date (median (IQR)) } \neq\end{array}$ & $1(0-3)$ & $2(0-3)$ & $0(0-3)$ & - & - \\
\hline None & $47(38.8)$ & $26(32.1)$ & $21(52.5)$ & - & Ref \\
\hline Some & 38 (31.4) & $24(29.6)$ & $14(35.0)$ & 0.47 & 0.72 (0.30 to 1.73$)$ \\
\hline All & $36(29.8)$ & 31 (38.3) & $5(12.5)$ & 0.004 & 0.20 (0.07 to 0.60$)$ \\
\hline
\end{tabular}

*Family members stay with the primary case at a short distance (within $1 \mathrm{~m}$ or 3 feet) for more than $10 \mathrm{~min}$ at a time. For example, they have dinner with the primary case around a table or watch TV sitting near.

†Before the primary case developed the illness, the primary case or his/her family contacts wear masks all the time at home.

$\ddagger$ When the primary case developed the illness, the primary case's family contacts wear masks all the time living with the primary case at home.

by frequent use of chlorine or ethanol based disinfectant in households and family members (including the primary case) wearing a mask at home before the primary case developed the illness (table 4).

\section{DISCUSSION}

This study confirms that the highest risk of household transmission is prior to symptom onset, but that precautionary NPIs, such as mask use, disinfection and social distancing in households can prevent COVID-19 transmission during the pandemic. This study is the first to confirm the effectiveness of mask use prior to symptom onset by family members, daily household disinfection and social distancing in the home. This could inform precautionary guidelines for families to reduce intrafamilial transmission in areas where there is high community transmission or other risk factors for COVID-19. Household transmission is a major driver of epidemic growth. $^{56}$ Further, in countries where health system capacity is exhausted, many people with infection are required to self-isolate at home, where their household contacts will be at risk of infection. In our study, the median family size of the 124 families was 4 (range 2-9), usually with children, parents and grandparents, which is similar to the social structure of most Chinese families. ${ }^{9}$ Therefore, the risk of SARS-CoV-2 household transmission is high if a primary case was introduced and no measure was adopted. We showed that NPIs are effective at preventing transmission, even in homes that are crowded and small. UFMU is a low risk intervention with potential public health benefits. ${ }^{3}{ }^{4}$ The results suggest that community face mask use is likely to be the most effective inside the household during severe epidemics.

Almost a quarter of family members became infected, and the findings suggest that the risk was highest either before symptom onset or early in the clinical illness, as most primary cases were hospitalised after diagnosis, and interventions were not effective if applied after symptom onset. In the univariate analysis, wearing a mask after illness onset was significant, but in multivariate analysis, only wearing it before symptom onset was effective. Viral load is highest in the 2 days before symptom onset and on the first day of symptoms, and up to $44 \%$ of transmission is during the pre-symptomatic period in settings with substantial household clustering. ${ }^{10} 11$ This supports UFMU, probably by reducing onward transmission from people in the pre-symptomatic phase of the illness ${ }^{12} 13$ as well as protecting well mask users. Randomised clinical trials of face masks in the household have confirmed protection against other respiratory viruses if compliant, if used within 36 hours of the primary case symptom onset, and alone or in combination with hand hygiene. ${ }^{1415}$ This study now provides specific evidence for UFMU in settings of high epidemic growth to protect against COVID-19. In our study, $91.2 \%$ $(103 / 113)$ of primary cases had a high score on hand hygiene, but it was not effective, confirming the results of previous randomised clinical trials which showed hand 
Table 3 Characteristics of the residence and household practices: univariable analysis between two family groups

\begin{tabular}{|c|c|c|c|c|c|}
\hline $\begin{array}{l}\text { Residence and household } \\
\text { practices }\end{array}$ & $\begin{array}{l}\text { Total }(n(\%)) \\
(n=121)\end{array}$ & $\begin{array}{l}\text { Families without } \\
\text { transmission }(\mathrm{n}(\%)) \\
(\mathrm{n}=81)\end{array}$ & $\begin{array}{l}\text { Families with } \\
\text { transmission }(\mathrm{n}(\%)) \\
(\mathrm{n}=40)\end{array}$ & $P$ value & $\begin{array}{l}\text { Unadjusted OR } \\
(95 \% \mathrm{Cl})\end{array}$ \\
\hline $\begin{array}{l}\text { Residential area per capita }\left(\mathrm{m}^{2}\right) \\
\text { (median }(\mathrm{IQR}) \text { ) }\end{array}$ & $25.0(17.3-35.0)$ & $28.0(18.0-35.8)$ & $20.0(16.9-31.8)$ & - & - \\
\hline$\leq 20$ & $50(41.3)$ & $30(37.1)$ & $20(50.0)$ & - & Ref \\
\hline $20-40$ & $49(40.5)$ & $36(44.4)$ & $13(32.5)$ & 0.16 & $0.54(0.23$ to 1.27$)$ \\
\hline$\geq 40$ & $22(18.2)$ & $15(18.5)$ & $7(17.5)$ & 0.51 & 0.70 (0.24 to 2.02$)$ \\
\hline $\begin{array}{l}\text { No of bedrooms per person } \\
\text { (median (IQR)) }\end{array}$ & $0.7(0.5-1.0)$ & $0.7(0.5-1.0)$ & $0.7(0.5-1.0)$ & - & - \\
\hline$\geq 1$ & $39(32.2)$ & $28(34.6)$ & $11(27.5)$ & - & Ref \\
\hline$<1$ & $82(67.8)$ & $53(65.4)$ & $29(72.5)$ & 0.49 & 1.34 (0.59 to 3.08$)$ \\
\hline No of washrooms (median (IQR)) & $1(1-2)$ & $1(1-2)$ & $1(1-2)$ & - & - \\
\hline 2 or more & $34(28.1)$ & $23(28.4)$ & $11(27.5)$ & - & Ref \\
\hline 1 & $87(71.9)$ & $58(71.6)$ & $29(72.5)$ & 0.87 & $1.07(0.46$ to 2.49$)$ \\
\hline $\begin{array}{l}\text { Frequency of room cleaning (wet } \\
\text { type) }\end{array}$ & - & - & - & & - \\
\hline Once in 1-2 days & $83(68.6)$ & 59 (72.8) & $24(60.0)$ & - & Ref \\
\hline Once in $>2$ days & 38 (31.4) & $22(27.2)$ & $16(40.0)$ & 0.11 & 1.90 (0.86 to 4.19$)$ \\
\hline $\begin{array}{l}\text { Frequency of chlorine or ethanol } \\
\text { based disinfectant use for house } \\
\text { cleaning* }\end{array}$ & - & - & - & - & - \\
\hline Once in 2 or more days & $86(71.1)$ & $50(61.7)$ & $36(90.0)$ & - & Ref \\
\hline Once a day or more & 35 (28.9) & $31(38.3)$ & $4(10.0)$ & 0.003 & $0.18(0.06$ to 0.55$)$ \\
\hline $\begin{array}{l}\text { Ventilation duration per day (hours) } \\
\text { (median (IQR))† }\end{array}$ & $2.0(1.0-6.0)$ & $3.0(1.5-8.0)$ & $1.8(1.0-4.0)$ & - & - \\
\hline$>1$ & 85 (70.2) & $62(76.5)$ & $23(57.5)$ & - & Ref \\
\hline$\leq 1$ & $36(29.8)$ & $19(23.5)$ & $17(42.5)$ & 0.02 & 2.55 (1.14 to 5.70$)$ \\
\hline
\end{tabular}

*When cleaning the house, disinfectant which contains chlorine or ethanol is used to disinfect the floor, door and window handles, indoor air, tables and toilets.

†Ventilation means the practice of opening the window to allow convection of indoor air.

\begin{tabular}{|c|c|c|c|}
\hline Risk factor & Adjusted OR & $95 \% \mathrm{Cl}$ & $P$ value \\
\hline Primary case has diarrhoea & - & - & - \\
\hline No & - & - & Ref \\
\hline Yes & 4.10 & (1.08 to 15.60$)$ & 0.04 \\
\hline Close contact at home with primary cases (within $1 \mathrm{~m}$ or 3 feet) (times) & - & - & - \\
\hline 0 & - & - & Ref \\
\hline $1-3$ & 3.30 & (1.05 to 10.40$)$ & 0.04 \\
\hline$\geq 4$ & 18.26 & (3.93 to 84.79 ) & $<0.001$ \\
\hline $\begin{array}{l}\text { No of family members (including primary case) wearing a mask at home } \\
\text { before the primary case's illness onset date }\end{array}$ & - & - & - \\
\hline None & - & - & Ref \\
\hline 1 or more & 0.21 & $(0.06$ to 0.79$)$ & 0.02 \\
\hline $\begin{array}{l}\text { Frequency of chlorine or ethanol based disinfectant use for house } \\
\text { cleaning }\end{array}$ & - & - & - \\
\hline Once in 2 or more days & - & - & Ref \\
\hline Once a day or more & 0.23 & (0.07 to 0.84$)$ & 0.03 \\
\hline
\end{tabular}


hygiene alone did not protect against respiratory transmissible viruses, but masks combined with hand hygiene did have effect. ${ }^{16}$

As the compliance of UFMU would be poor in the home, there was difficulty and also no necessity for everyone to wear masks at home. We recommended that those families with members who were at risk of getting infected with SARS-CoV-2 (such as ever having contact with a COVID-19 patient, medical workers caring for a COVID-19 patient or having a history of travelling to high risk areas) should apply UFMU to reduce the risk of household transmission.

This study showed that social distancing within the home is effective and having close contact (within 1 $\mathrm{m}$ or 3 feet, such as eating around a table or sitting together watching TV) is a risk factor for transmission. The study also provides evidence of effectiveness of chlorine or ethanol based household disinfection in areas with high community transmission, or where one family member is a health worker, or where there is a risk of COVID-19, such as during home quarantine, consistent with advice provided by local health authorities or organisations. ${ }^{17}$ Diarrhoea as a symptom in the primary case is also a risk factor for SARS-CoV-2 transmission within families, which highlights the importance of disinfection of the bathroom and toilet, as well as closing the toilet lid when flushing to prevent aerosolisation of the virus.

Our study has limitations. Telephone interview has inherent limitations, including recall bias. It would take about $20 \mathrm{~min}$ to complete an interview, and $95 \%$ $(118 / 124)$ of interviews were rated as informative by the interviewers. The evaluation results of mask wearing were reliable, but we did not collect data on the concentration of disinfectant used by families. The strengths of the study were that we had complete follow-up data and were able to accurately ascertain the incidence of secondary transmission in the cohort.

\section{CONCLUSIONS}

Household transmission in the pre-symptomatic or early symptomatic period of COVID-19 is a driver of epidemic growth and any measure aimed at reducing this can flatten the curve. This study reinforces the high risk of transmission in households but importantly shows that UFMU and hygiene measures can significantly reduce the risk of household transmission of COVID-19, independent of household size or crowding. This is the first study to show the effectiveness of precautionary mask use, social distancing and regular disinfection in the household, and can inform guidelines for prevention of household transmission. The results may also be informative for families of high risk groups, such as health workers, quarantined individuals or situations where cases of COVID-19 have to be managed at home.

\section{Author affiliations}

${ }^{1}$ Institute for Infectious Disease and Endemic Disease Control, Beijing Center for Disease Prevention and Control, Beijing Research Center for Preventive medicine, Beijing, China

${ }^{2}$ State Key Laboratory of Remote Sensing Science, College of Global Change and Earth System Science, Beijing Normal University, Beijing, China

${ }^{3}$ Office of Beijing Center for Global Health, Beijing Center for Disease Prevention and Control, Beijing Research Center for Preventive medicine, Beijing, China

${ }^{4}$ Institute for nutrition and food hygiene, Beijing Center for Disease Prevention and Control, Beijing Research Center for Preventive medicine, Beijing, China

${ }^{5}$ Department of Environmental and Occupational Health, School of Public Health, University of Nevada, Las Vegas, Nevada, USA

${ }^{6}$ Arizona State University College of Health Solutions, Phoenix, Arizona, USA ${ }^{7}$ Kirby institute, Faculty of Medicine, the University of New South Wales, Sydney, New South Wales, Australia

Acknowledgements We thank the staff members in the district and municipal Centres for Disease Prevention and Control, and medical settings in Beijing for conducting field investigation, specimen collection, laboratory detection and case reporting. We also thank all patients and families involved in the study.

Contributors All authors approved the final draft of the manuscript. The corresponding authors attests that all listed authors meet authorship criteria and that no others meeting the criteria have been omitted.

Funding This work was supported by Beijing Science and Technology Planning Project (Z201100005420010).

\section{Competing interests None declared.}

Patient and public involvement Patients and/or the public were not involved in the design, or conduct, or reporting, or dissemination plans of this research.

Patient consent for publication Not required.

Provenance and peer review Not commissioned; externally peer reviewed.

Data availability statement No additional data available.

Open access This is an open access article distributed in accordance with the Creative Commons Attribution Non Commercial (CC BY-NC 4.0) license, which permits others to distribute, remix, adapt, build upon this work non-commercially, and license their derivative works on different terms, provided the original work is properly cited, appropriate credit is given, any changes made indicated, and the use is non-commercial. See: http://creativecommons.org/licenses/by-nc/4.0/.

\section{REFERENCES}

1 Tian $\mathrm{H}$, Liu Y, Li Y, et al. An investigation of transmission control measures during the first 50 days of the COVID-19 epidemic in China. Science 2020;368:638-42.

2 Centers for Disease Control and Prevention. Recommendation regarding the use of cloth face coverings, especially in areas of significant community-based transmission. Available: https://www. cdc.gov/coronavirus/2019-ncov/prevent-getting-sick/cloth-facecover.html [Accessed 15 Apr 2020].

3 Greenhalgh T, Schmid MB, Czypionka T, et al. Face masks for the public during the covid-19 crisis. BMJ 2020;369:m1435.

4 Javid B, Weekes MP, Matheso NJ. Covid-19: should the public wear face masks? Yes-population benefits are plausible and harms unlikely. BMJ 2020;369:m1442.

5 World Health Organization. Report of the WHO-China joint mission on coronavirus disease 2019 (COVID-19), 2020. Available: https:// www.who.int/docs/default-source/coronaviruse/who-china-jointmission-on-covid-19-final-report-1100hr-28feb2020-11mar-update. pdf?sfvrsn=1a13fda0_2 [Accessed 15 Apr 2020].

6 Yang HY, Xu J, Li Y, et al. [The preliminary analysis on the characteristics of the cluster for the COVID-19]. Zhonghua Liu Xing Bing Xue Za Zhi 2020;41:623-8.

7 National Health Commission. New coronavirus pneumonia prevention and control program (5th edition) (in Chinese). Available: http://www.nhc.gov.cn/jkj/s3577/202002/a5d6f7b8c48c451c87db a14889b30147.shtml [Accessed 15 Apr 2020].

8 Zhang YP, The Novel Coronavirus Pneumonia Emergency Response Epidemiology Team. The epidemiological characteristics of an outbreak of 2019 novel coronavirus diseases (COVID-19) - China, 2020. China CDC Weekly 2020;2:11322. 
9 National Bureau of Statistics. China statistical Yearbook-2019 (in Chinese). Available: http://www.stats.gov.cn/tjsj/ndsj/2019/indexch. $\mathrm{htm}$ [Accessed 3 May 2020].

10 Wölfel R, Corman VM, Guggemos W, et al. Virological assessment of hospitalized patients with COVID-2019. Nature 2020. doi:10.1038/s41586-020-2196-x. [Epub ahead of print: 01 Apr 2020].

$11 \mathrm{He}$ X, Lau EHY, Wu P, et al. Temporal dynamics in viral shedding and transmissibility of COVID-19. Nat Med 2020;26:672-5.

12 Tong Z-D, Tang A, Li K-F, et al. Potential presymptomatic transmission of SARS-CoV-2, Zhejiang Province, China, 2020. Emerg Infect Dis 2020;26:1052-4.

13 Bai Y, Yao L, Wei T, et al. Presumed asymptomatic carrier transmission of COVID-19. JAMA 2020. doi:10.1001/ jama.2020.2565. [Epub ahead of print: 21 Feb 2020].
14 Maclntyre CR, Cauchemez S, Dwyer DE, et al. Face mask use and control of respiratory virus transmission in households. Emerg Infect Dis 2009;15:233-41.

15 Cowling BJ, Chan K-H, Fang VJ, et al. Facemasks and hand hygiene to prevent influenza transmission in households: a cluster randomized trial. Ann Intern Med 2009;151:437-46.

16 Wong VWY, Cowling BJ, Aiello AE. Hand hygiene and risk of influenza virus infections in the community: a systematic review and meta-analysis. Epidemiol Infect 2014;142:922-32.

17 Centers for Disease Control and Prevention. Cleaning and disinfection for households: interim recommendations for U.S. households with suspected or confirmed coronavirus disease 2019 (COVID-19). Available: https://www.cdc.gov/coronavirus/2019-ncov/ prevent-getting-sick/cleaning-disinfection.html?CDC_AA_refVal= https\%3A\%2F\%2Fwww.cdc.gov\%2Fcoronavirus\%2F2019-ncov\% 2Fprepare\%2Fcleaning-disinfection.html [Accessed 15 Apr 2020]. 